\title{
Seasonal occurrence, abundance and flight activities of anisopterous dragonflies
}

\begin{abstract}
The dragonflies were studied as indicators for healthy environment and good atmosphere based on the seasonal occurrence, abundance and flight activities aspects at National Kandawgyi Gardens (NKGs) from June 2008 to September 2011. The 30 species of dragonflies are distributed among three families. Dragonflies belonging to order Odonata are a well- known group of insects that are widely distributed all over the world and many people appreciate their striking colours and acrobatic flights. They are widely distributed in variable habitats such as ponds, lakes, streams, rivers and canals of all sizes. Since NKGs is diverse habitat, such as a lake, ponds, freshwater swamp, peat swamp, etc., different habitats are suitable for feeding, mating, perching and reproduction of many dragonfly species. The present research pursued to support the combination of conservation measures to ensure the continued survival of dragonflies and NKGs not only attracts human but a variety of living assets, including the dragonflies.
\end{abstract}

Keywords: seasonal occurrence, abundance and flight activities of anisopterous dragonflies, National Kandawgyi Gardens (NKGs)
Volume 4 Issue 4 - 2019

\section{Yin Yin Nu,' Si Si Hla Bu²}

'Assistant Lecturer, Zoology Department, Mawlamyine University Myanmar, Myanmar

${ }^{2}$ Pathein University, Myanmar

Correspondence: : Dr Yin Yin Nu,Assistant Lecturer, Zoology Department, Mawlamyine University Myanmar, Myanmar, Tel +095 940262946I,Email yinyinu@gmail.com

Received: July 04, 2019 | Published: July 17, 2019

\section{Introduction}

The dragonflies (Anisoptera) and damselflies (Zygoptera) belonging to order Odonata, constitute well-known, widely distributed, beautiful and fascinating insects. Their large size makes them valuable for quickly assessing water quality and for the study of insect behaviour.'

Dragonflies are strong fliers because the flight muscles are directly attached to four individual net-veined wings. This individual wing attachment is found in only a few groups of insects. They have mastered the use of their muscled wings and they are able to hover like a helicopter, fly backwards and go from a full-stop position to rapid speeds almost instantly. It can fly at speeds of nearly $100 \mathrm{kph}$. Dragonflies have had a very long time to evolve such specialized flying techniques, considering that their fossil records go back over 300 million years to the Carboniferous Period. ${ }^{2}$

The flight of the dragonfly is impressive. They are masters of the air, able to maneuver in ways equaled by few other animals. Flight is very fast and they catch their prey in flight. They have well developed mandibles that form a 'feeding basket' to devour their prey. The eyes are large and compound, comprising numerous smaller facets (with up to 30,000 facets in some species) with the best eyesight among insects. This feature gives dragonflies a very wide field of vision, enabling them to see prey up to $360^{\circ} .^{3}$

Territorians are well aware of the seasonal changes in abundance of dragonflies, with large numbers appearing towards the end of the wet season. ${ }^{3}$ Because warmth is needed for activity and an efficient metabolism, most dragonflies disappear to protected perches on cool days or when the sun disappears behind a cloud. Despite the fact that insects are "cold blooded," many dragonflies maintain an internal temperature as high as $110^{\circ} \mathrm{F}$. This is accomplished by the burning of calories during physical exertion and by staying in the sun. A cold dragonfly preparing to get the day started will shiver its wings to create heat in its thorax until it has warmed itself enough to take flight. Some dragonflies have adapted to cooler weather as a method of allowing early or late season emergence or to take advantage of the plethora of insect life that becomes active at dusk. Some species will be seen flying well after sunset on moonlit evenings or under street lights. Certain species of dragonfly migrate, either en masse or individually. Dragonflies follow weather fronts, fleeing cold fronts in the fall on their way south and chasing warm fronts in the spring when moving north.

Odonata species are sensitive to human disturbances. Of these two groups, dragonflies are particularly sensitive to conditions of light and shade. Dragonflies need sunny warm weather to fly; the temperature below $25^{\circ} \mathrm{C}$ slowed the activity whereas an optimal temperature above $30{ }^{\circ} \mathrm{C}$ increased activity. If it is too cold or wet, they usually hide in vegetation. ${ }^{4}$

Seasonal regulation is the restriction of development to a particular season through an array of responses. ${ }^{5}$ In temperate region, the emergence period of odonates is restricted ${ }^{6}$ despite differences in development rate accumulated between individuals in the larval stage due to differential hatch dates ${ }^{7}$ or differences in the nutritional condition of individuals. ${ }^{8}$ Their distribution, seasonality and interhabitat variation are strongly restricted by climatic factors, especially temperature. This seasonal difference in competition was attributed to fluctuations in resource abundance. ${ }^{9}$

Their sensitivity to structural habitat quality such as forest cover, water limpidity and amphibious habits make Odonata well suited for evaluating environmental change in the long term (biogeography, climatology) and in the short term (conservation biology), both above and below the water surface. Adult Odonata are highly sensitive to the structure of their terrestrial habitats (e.g. degree of shading). As a consequence, Odonata respond strongly to habitat changes, such as those related to deforestation and erosion. ${ }^{5}$

Aquatic habitats, the focal point of their life histories, are easy to locate, and their diurnal activity and high densities make Odonata easy to study. Particularly in forest and freshwater ecosystems, an 
emphasis on Odonata research seems beneficial as a baseline for biodiversity and watershed conservation.

The absence of certain expected species, as well as the generally low individual numbers observed, may be explained by seasonality. High and fluctuation water levels are a possible reason why activity of adult dragonflies is low during the transition from wet to dry season. ${ }^{10}$

A suitable habitat is determined by temperature and water chemistry which is then influenced by rainfall, watershed and aquatic vegetation. The other important factor influencing habitat selection is predation as discussed by Saunders. ${ }^{11}$

Keeping with the matter, the objectives of the present study are:

a. To relate the fluctuation of dragonfly species with light intensity level

b. To investigate the abundance of dragonfly species depending on different habitats

c. To record the seasonal occurrence of dragonfly species in associated with environmental factors.

\section{Materials and methods}

\section{Study area}

The specimens were collected from the chosen sites in National Kandawgyi Gardens (NKGs), situated at $21^{\circ} 99^{\prime}$ North, and $96^{\circ} 46^{\prime}$ East. The area of NKGs is 154.84 hectare at $1072.12 \mathrm{~m}$ above sea level (Figure 1). Average temperature is $36^{\circ} \mathrm{C}$ at the highest while $2^{\circ} \mathrm{C}$ at the lowest. The annual rainfall is $1615.38 \mathrm{~mm}$ in April through October. Humidity ranges between 48-89\% (Meteorological and Hydrology Department, Mandalay).

\section{Study sites}

The seven habitats studied are public area (I), bamboo forest (II), swamp forest (III), orchard (IV), adjacent to natural forest (V), flower beds (VI) and ponds (VII) in NKGs (Figure 1).

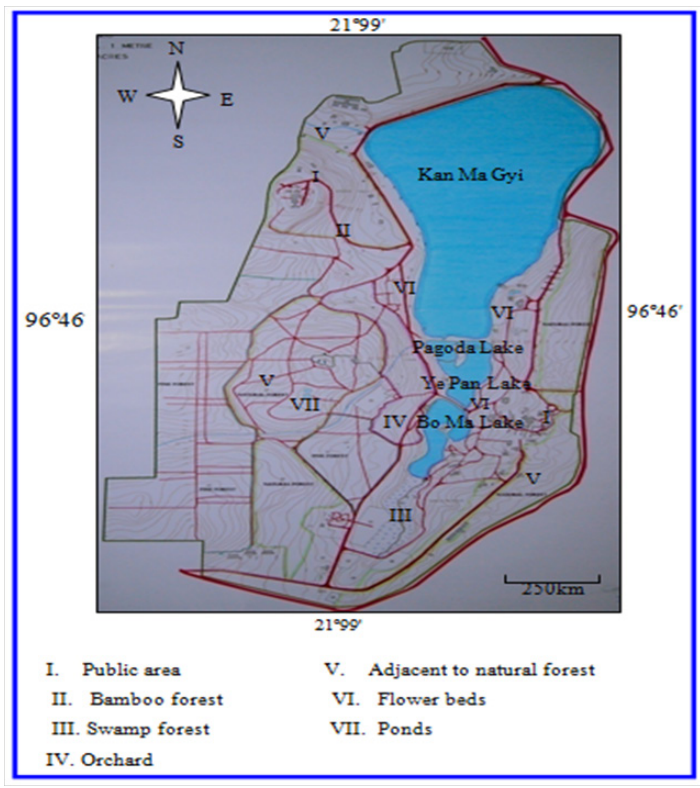

Figure I Study sites in NKGs source: forest department.
Four aquatic habitats (Kan Ma Gyi, Pagoda Lake,Ye Pan Lake and Bo Ma Lake) located in the study area were focused to study the relationship between species abundance and light intensity level (Figure 1).

\section{Study period}

The study for the seasonal occurrence, abundance and flight activities of Anisopterous dragonfly species was conducted at National Kandawgyi Gardens (NKGs), Pyin Oo Lwin Township during the period from June 2008 to December 2010.

\section{Collection of the specimens}

Since these insects are essentially sun loving insects and most species feed by day especially in strong sun, the specimens were mainly collected during 09:00h to 17:00 h time. Adult dragonflies were collected by a long-handed aerial net. Collection was mainly conducted along and around weedy places of NKGs within. The photos of dragonflies were taken alive immediately Cannon Eos 40D digital Camera with 400 Zoom Lens both in natural and mounted conditions. Data on collection and information such as locality, date, time were also recoded.

\section{Collection of data}

Each sampling site was visited once a month. The data for light intensity was recorded using light level sensormeter (lux) (MN1604), then chosen sites (Kan Ma Gyi, Pagoda Lake, Ye Pan Lake and Bo Ma Lake). The flight activities of dragonfly species were recorded for 10 minutes during 09:00-10:00h and 14:00-16:00h. The abundance of dragonfly species was estimated using point count method. Counting from a standing in one spot and recording all the dragonfly species at either a fixed distance or unlimited distance for 15 minutes from 09:00-11:00h and 13:00-17:00h. The photos of dragonflies were taken immediately with digital camera after viewing.

\section{Identification of the specimens}

Specimens were indentified to subspecies level, based mainly on the morphological criteria along with some anatomical consideration as outlined by Fraser ${ }^{12-14}$ and Orr $^{15}$. The identified specimens were spread, pinned, dried and stored in dry insect boxes along with the respective specific names. The collections were identified to the lowest possible taxa whenever possible. The mounted specimens were also photographically recorded for detail description. Terminology was adopted by Fraser. ${ }^{12-14}$

\section{Analysis of data}

The data collected was analyzed as the following:

Species composition $=\frac{\text { total no. of individuals in each species }}{\text { total no.of individuals in all species }} \times 100$

(Bisht et al., ${ }^{16}$ )

Relative abundance $=\frac{\text { no. of individuals of a species }}{\text { total no. of individuals in all species }}$

The average relative abundance was categorized as follows:

a) Uncommon $(\mathrm{uC})$ =having relative abundance less than 0.0100 
b) Common (C) =having relative abundance of 0.0100 and above but lessthan 0.0500

c) Very common $(\mathrm{vC})=$ having relative abundance of 0.0500 and above (Bisht et al., ${ }^{16}$ )

\section{Environmental factors}

The temperature, humidity, wind force and rainfall (Pyin Oo Lwin) data were obtained from Meteorological Department, Mandalay.

\section{Statistical analysis}

The distribution of dragonfly species and their population different among all study sites was calculated using one way analysis of variance (ANOVA). It was done using the programme of Statistical Package for Social Sciences Version 15.0.

\section{Results}

\section{Dragonfly species recorded based on habitat type}

A total of 17 species of Anisoptera, confined to two families, two subfamilies and 11 genera were recorded during the study period of 2008. Only one species Pantala flavescens was found in five habitat types while four species (Ictinogomphus decoratus melaenops, Orthetrum pruinosum neglectum, $O$. triangulare triangulare and Trithemis pallidinervis) in only single habitat. Seven, four and one species were found in two, three and four habitats respectively (Table $1)$.

A total of 26 species of Anisoptera, under three families, three subfamilies and 18 genera were recorded during the study period of 2009. Two species Diplacodes trivialis and Pantala flavescens was found in six habitat types while seven species (Polycanthagyna erythromelas, Diplacodes nebulosa, Hydrobasileus croceus, Orthetrum sabina sabina, Tholymis tillarga, Trithemis pallidinervis and Urothemis signata) in only single habitat. Nine, seven and one species were found in two, three and four habitats respectively (Table $1)$.

A total of 28 species of Anisoptera, to three families, belonging to three subfamilies and 18 genera were recorded during the study period of 2010. Only one species Pantala flavescens were found in six habitat types while seven species (Polycanthagyna erythromelas, Brachydiplax farinosa, Brachythemis contaminata, Diplacodes nebulosa, Orthetrum glaucum, Trithemis festiva and Urothemis signata) in only single habitat. Five, one, seven and seven species were found in five, four, three and two habitats respectively (Table 1).

A total of 30 species of Anisoptera, confined to three families, three subfamilies and 19 genera were recorded during the study period from June 2008 to December 2010. Four species (Diplacodes trivialis, Neurothemis fulvia, Orthetrum luzonicum and Pantala flavescens) were recorded in six habitat types while five species (Polycanthagyna erythromelas, Diplacodes nebulosa, Tholymis tillarga, Trithemis festiva and Urothemis signata) in only single habitat and nine species (Ictinogomphus decoratus melaenops, Anax guttatus, Brachydiplax farinosa, Brachythemis contaminata, Orthetrum glaucum, Rhodothemis rufa, Tetrathemis irregularis, T. platyptera and Trithemis pallidinervis) were found in two habitat types. Seven, five and two species were found in three, four and five habitats respectively (Table 1).
During the study period, the number of dragonflies dispersed in seven types of habitats. The highest of (2060) individuals were observed in public area followed by flower beds (1257) regardless of the species number. The least number was recorded in bamboo forest (11) and orchard (5) (Table 3). In addition, family Libellulidae comprised the highest species number (27) and the members of families Aeshnidae and Gomphidae representing two and one species respectively (Table 3) (Figures 2-4).

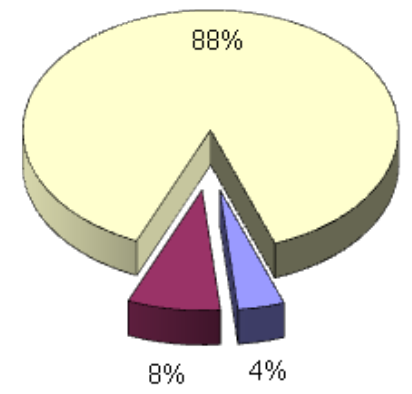

口Gomphidae

aeshnidae

口Libellulidae

Figure $\mathbf{2}$ The percentage of species composition under different families.

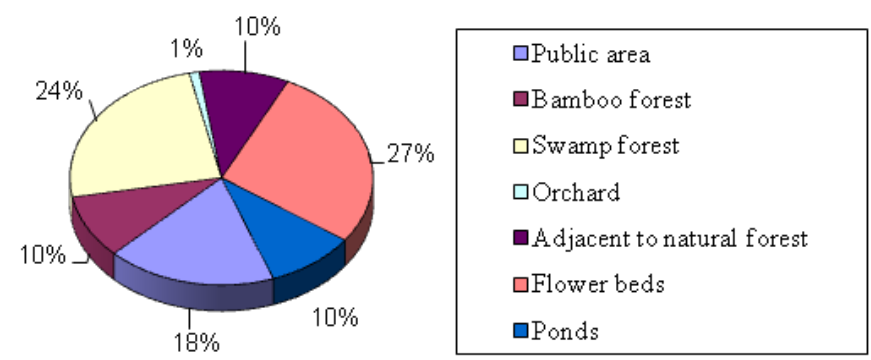

Figure 3 The percentage of species composition at different study sites.

ANOVA revealed that there is a significant difference between study sites in terms of species number $(\mathrm{F}=9.423, \mathrm{p}<0.05)$. However, no significance was observed between study sites when the individuals number of each species recorded are concerned $(\mathrm{F}=2.681, \mathrm{p}>0.05)$. Tukey HSD test further showed that significant difference occurred between bamboo forest and swamp forest, bamboo forest and adjacent to natural forest, bamboo forest and flower beds, swamp forest and orchard, swamp forest and adjacent to natural forest, swamp forest and ponds, orchard and flower beds, adjacent to natural forest and flower beds, flower beds and ponds, ponds and swamp forest $(\mathrm{p}<0.05)$.

\section{Seasonal occurrence of dragonfly species related to environmental factors}

In 2009, it was noted that the occurrence of dragonfly species varied along with the season. The maximum species number occurred in March, May, July, August, September and October with the number of $14,14,15,14,17$ and 17 respectively. In November, 13 species were recorded out of total 26 species. However, no dragonfly was recorded in December and January (Table 2). The high number of species coincided with high rainfall and temperature. The high number of species occurred within the temperature range of $22.7-23.5^{\circ} \mathrm{C}$. 


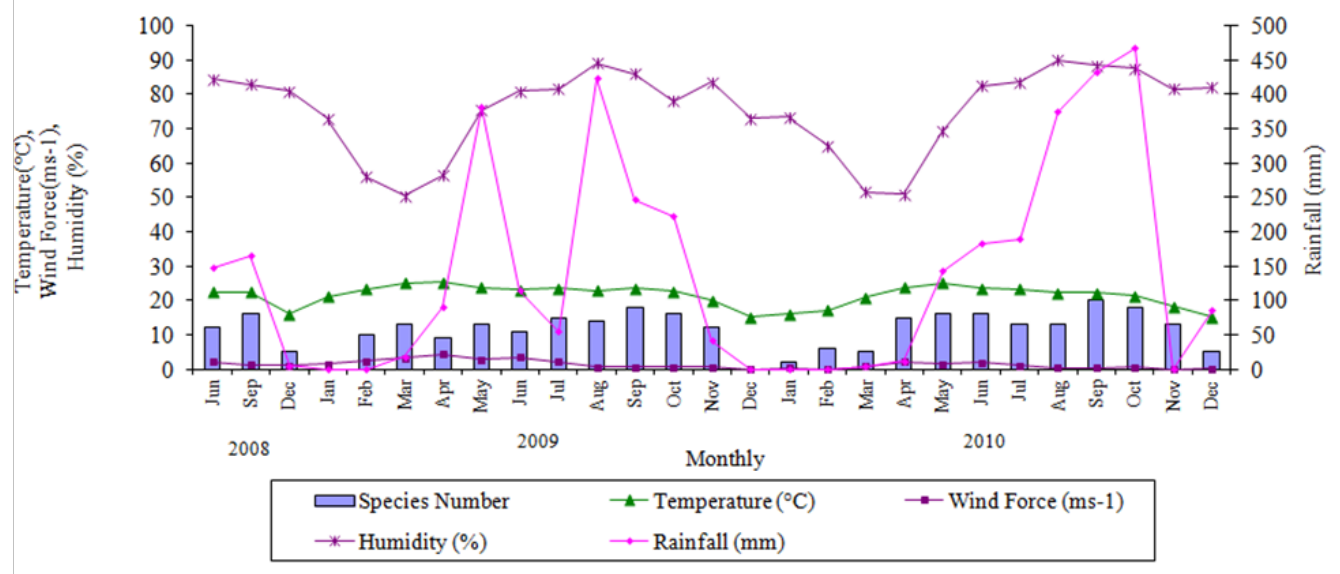

Figure 4 Relationship between species number and environmental factors based on monthly data.

In 2010, it was noted that the occurrence of dragonfly species varied along with the season. The maximum species number occurred in April, June, September and October with the number of 16, 16, 24 and 21 respectively. In the months of November, 13 species each was recorded out of total 28 species. However, lowest number of the individuals was found in January (Table 3). The high number of species coincided with high monthly rainfall and also with temperature. The high number of species occurred within the temperature range of $22.7-23.5^{\circ} \mathrm{C}$.

\section{Species composition and relative abundance of dragonfly species}

Total of 17 species were recorded during 2008, four species were recorded to be uncommon, seven species are common, and seven species are very common. During the study period of 2009 and 2010,
11 and 16 species were recorded to be uncommon, ten and nine species are common, five and three species are very common (Table 4).

Of 30 species recorded in the present study, four species Ictinogomphus decoratus melaelnops, Polycanthagyna erythromelas, Rhyothemis triangularis and Tetrathemis irregularis were not among those recorded by the previous workers (Table 5).

\section{The flight activities of dragonfly species and individual number related to time and light intensity}

The flight activities of dragonfly in terms of species and individual number were related with time, location and light intensity level (lux) during limited hours (Figures 5A-8B). Out of the four study sites, the highest number of 16 species was recorded from Ye Pan Lake both in the morning and afternoon (Figures 7A, 7B). The flight activities pattern of dragonflies was similar in four sites.

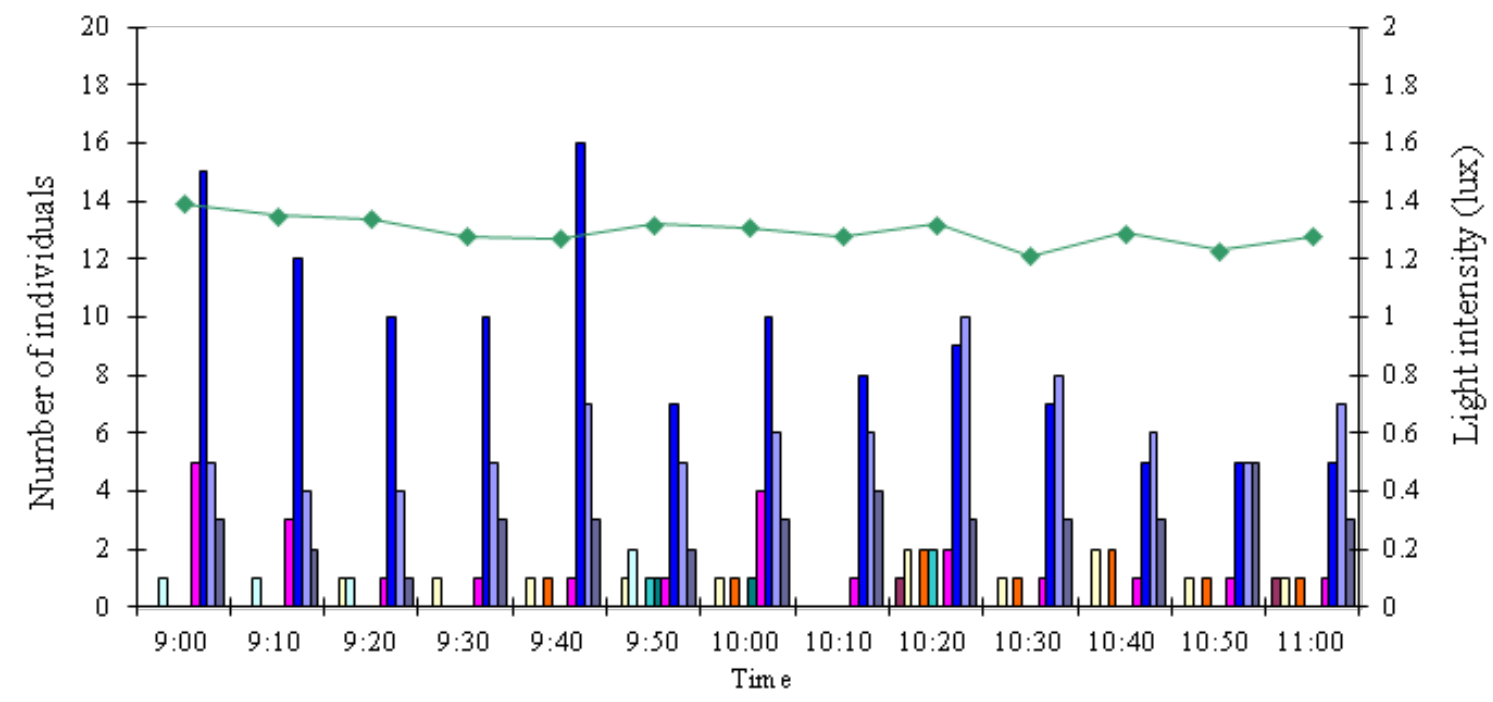

\begin{tabular}{|c|c|}
\hline $\begin{array}{l}\square \text { Ictinogomphus decoratus melaenops } \\
\square \text { Brachythemis contaminata } \\
\square \text { Diplacodes trivialis } \\
\square \text { Orthetrum sabina sabina } \\
\square \text { Trithemis aurora } \\
\longrightarrow \text { Light intensity (lux) }\end{array}$ & $\begin{array}{l}\square \text { Anax guttatus } \\
\square \text { Crocothemis servilia servilia } \\
\text { Orthetrum luzonicum } \\
\text { Pantala flavescens } \\
\text { Trithemis pallidinervis }\end{array}$ \\
\hline
\end{tabular}

Figure 5(A) The flight activities (morning) of dragonfly in terms of the number of species and individual related to time and light intensity at Kan Ma Gyi. 


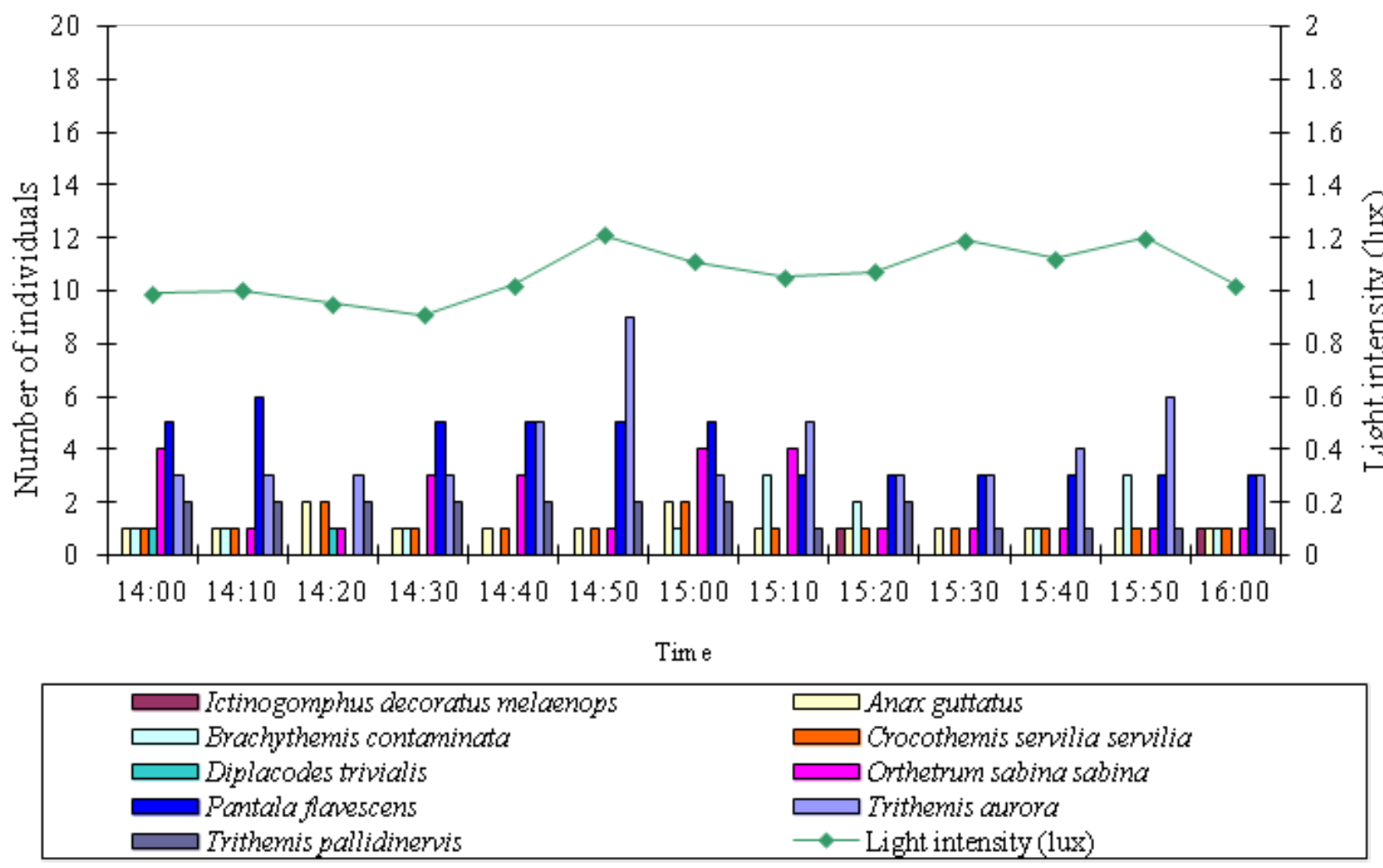

Figure 5(B) The flight activities (afternoon) of dragonfly in terms of the number of species and individual related to time and light intensity at Kan Ma Gyi.

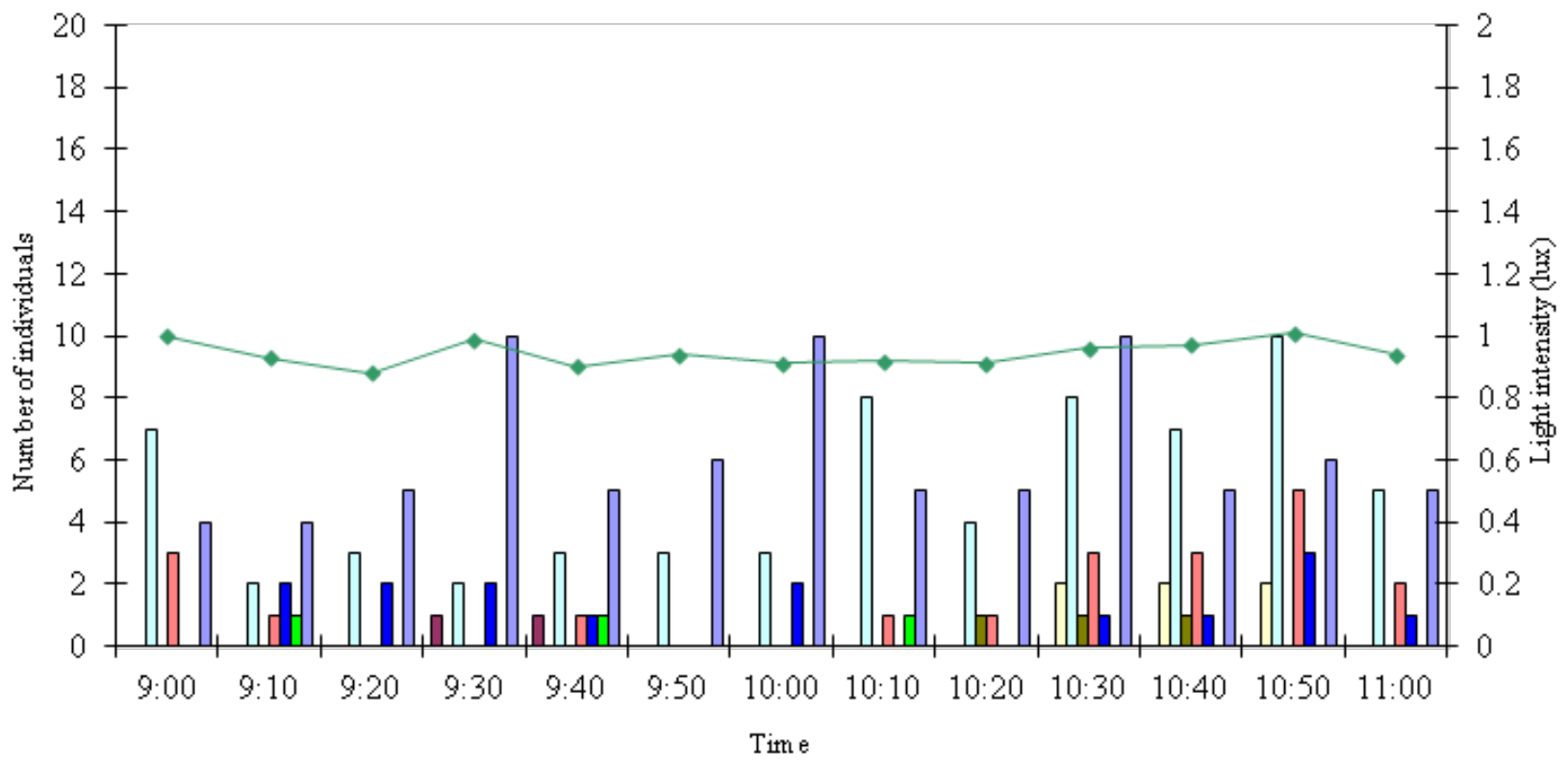

\begin{tabular}{|c|c|}
\hline $\begin{array}{l}\square \text { Ictinogomphus decoratus melaenops } \\
\text { Brachythemis contaminata } \\
\text { Orthetrum sabina sabina } \\
\text { Rhyothemis plutonia } \\
\rightarrow \text { Light intensity (lux) }\end{array}$ & $\begin{array}{l}\square \text { Anax guttatus } \\
\square \text { Orthetrum pruinosum neglectum } \\
\text { Pantala flavescens } \\
\text { Trithemis aurora }\end{array}$ \\
\hline
\end{tabular}

Figure 6(A) The flight activities (morning) of dragonflies in terms of the number of species and individual related to time and light intensity at Pagoda Lake. 


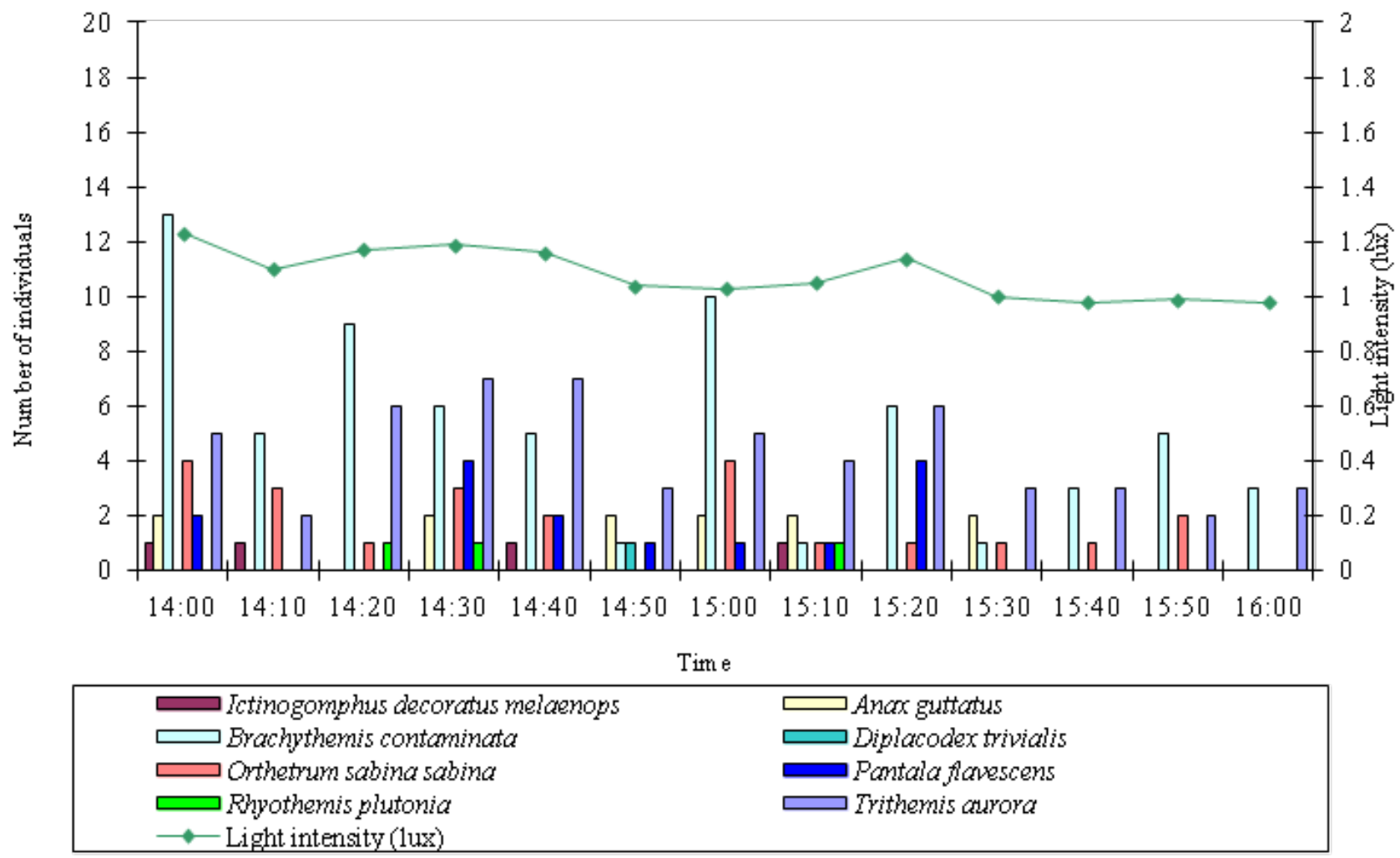

Figure 6(B) The flight activities (afternoon) of dragonfly in terms of the number of species and individual related to time and light intensity at Pagoda Lake.

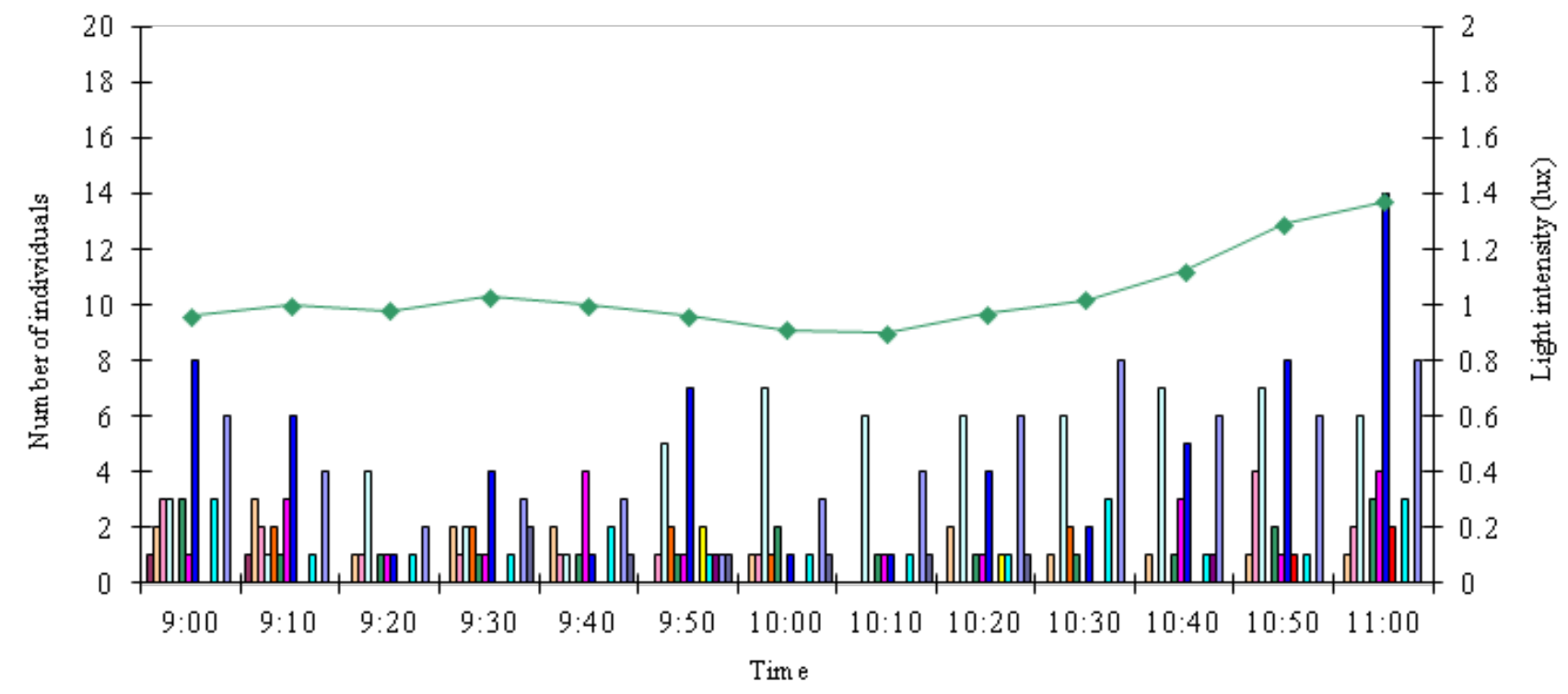

\begin{tabular}{|c|c|}
\hline $\begin{array}{l}\text { Ictinogomphus decoratus melaenops } \\
\text { Brachydiplax forinosa } \\
\text { Crocothemis servilia servilia } \\
\text { Onthetrum sabina sabina } \\
\text { Rhodothemis rufa } \\
\text { Rhyothemis triangularis } \\
\text { Trithemis aurora } \\
\text { - Light intensity (lux) }\end{array}$ & $\begin{array}{l}\square \text { Acisoma panorpoides panorpoides } \\
\square \text { Brachythemis contaminata } \\
\text { Orthetrum luzonicum } \\
\text { Pantala flavescens } \\
\text { Rhyothemis phyllis } \\
\text { Rhyothemis variegata variegata } \\
\text { Trithemis pallidinervis }\end{array}$ \\
\hline
\end{tabular}

Figure 7(A) The flight activities (morning) of dragonfly in terms of the number of species and individual related to time and light intensity at Ye Pan Lake. 


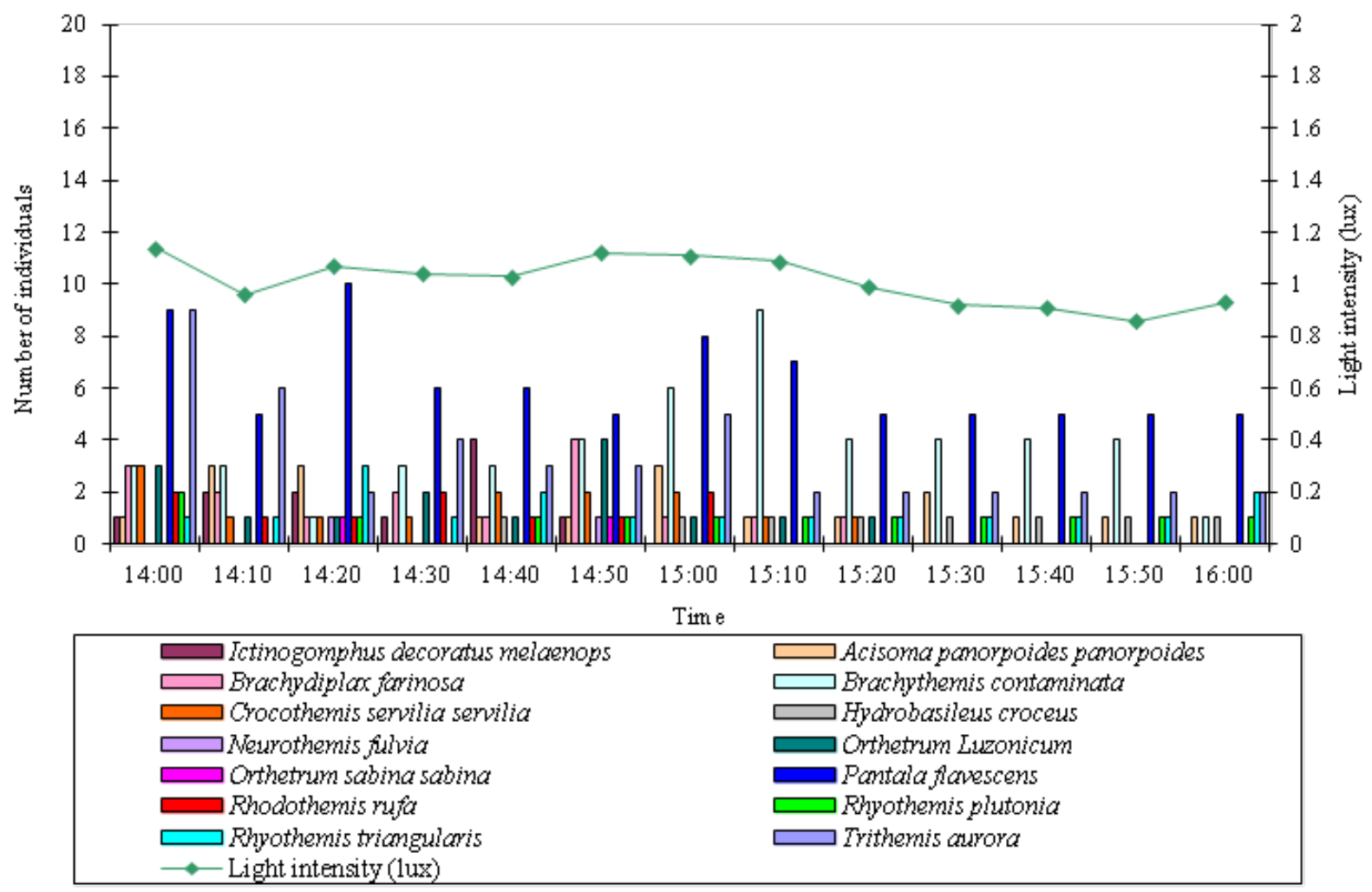

Figure 7(B) The flight activities (afternoon) of dragonfly in terms of the number of species and individual related to time and light intensity at Ye Pan Lake.

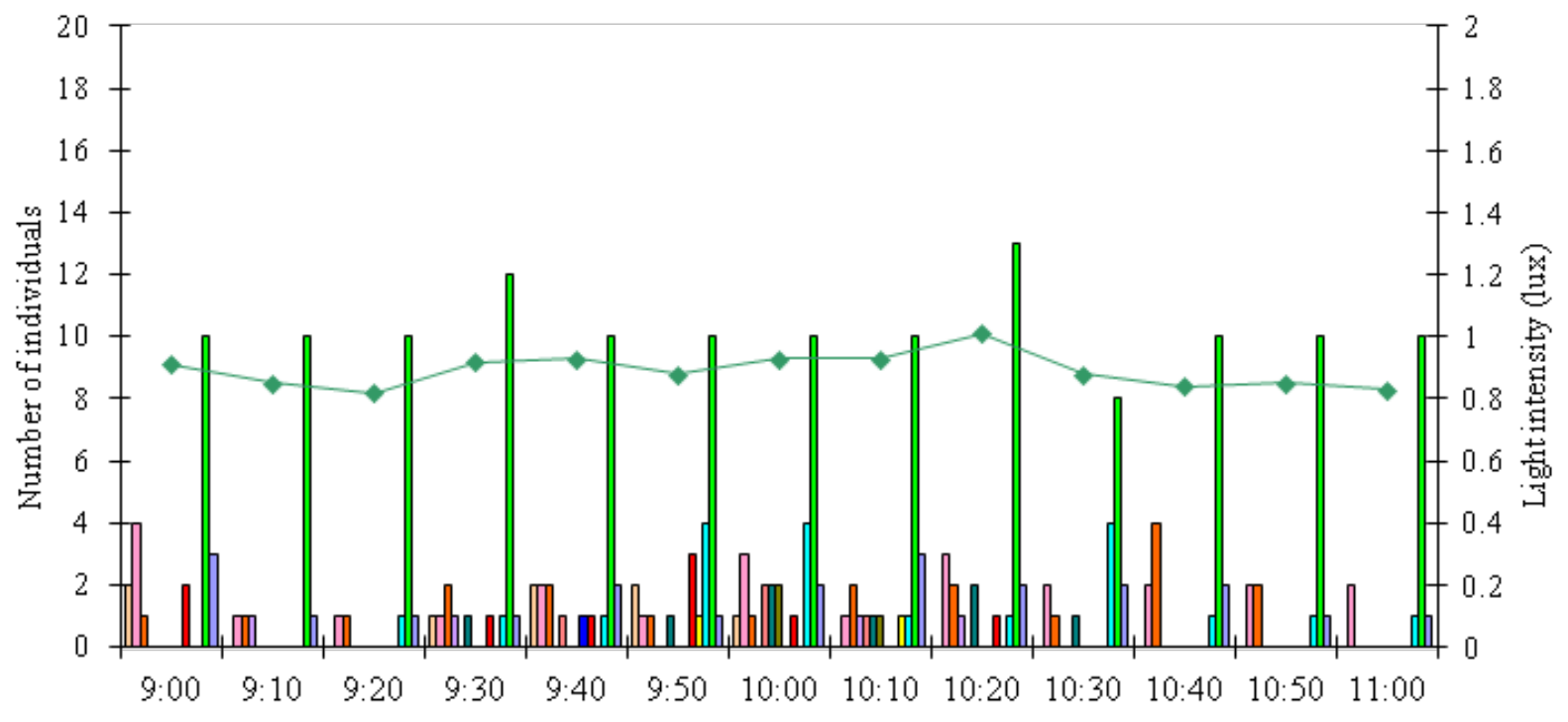

Time

\begin{tabular}{|c|c|}
\hline $\begin{array}{l}\text { Acisoma panorpoides ponorpoides } \\
\text { Crocothemis servilia servilia } \\
\text { Orthetrum glaucum } \\
\text { Onthetrum pruinosum neglectum } \\
\text { Rhodothemis rufa } \\
\text { Ryyothemis triangularis } \\
\text { Trithemis aurora }\end{array}$ & $\begin{array}{l}\text { Brachydiplax farinosa } \\
\text { Neurothemis fulvia } \\
\text { Orthetrum luzonicum } \\
\text { Pantala flavescens } \\
\text { Ryyothemis phyllis } \\
\square \text { Rhyothemis plutonia } \\
\text { Light intensity (lux) }\end{array}$ \\
\hline
\end{tabular}

Figure 8(A) The flight activities (morning) of dragonfly in terms of the number of species and individual related to time and light intensity at Bo Ma Lake. 


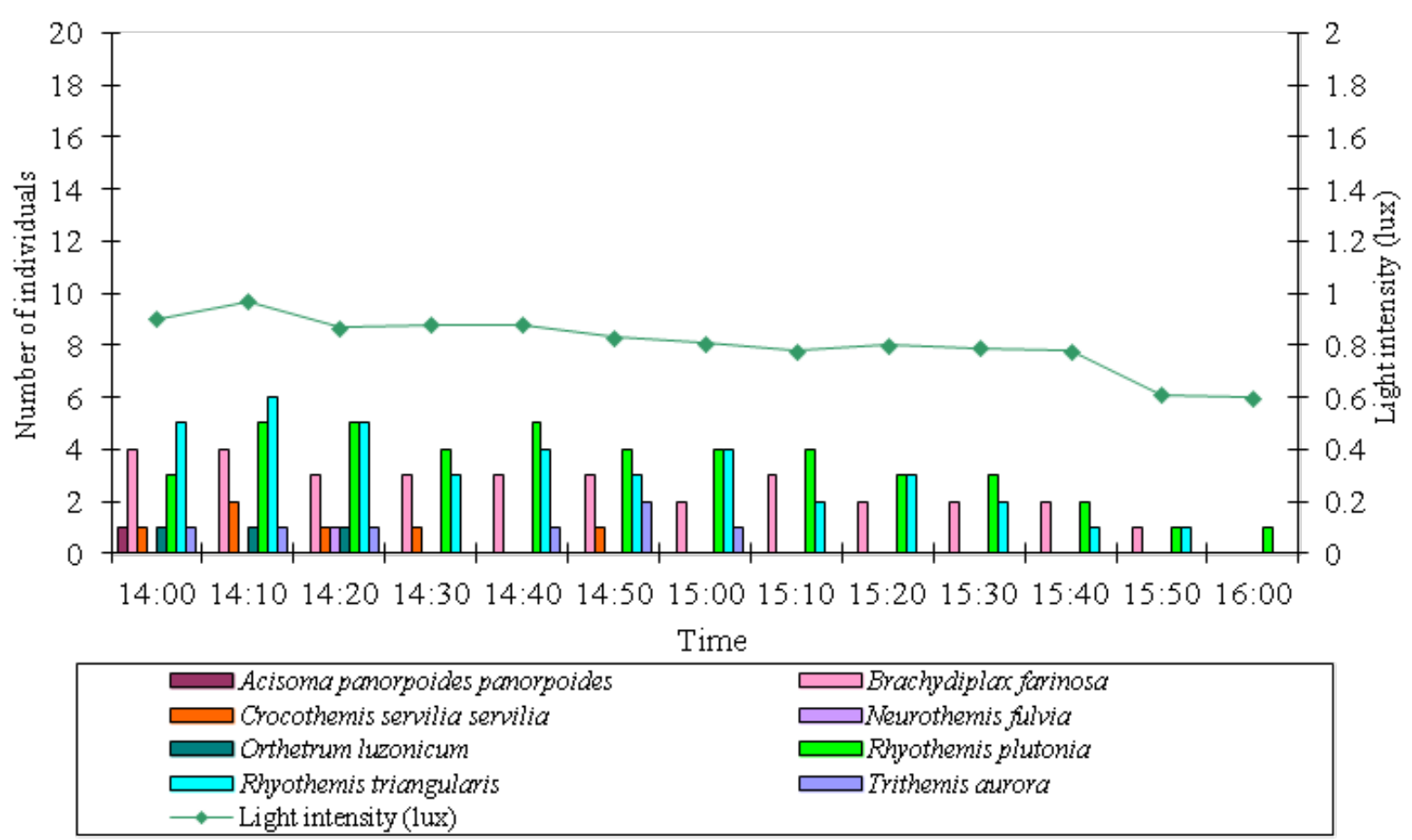

Figure 8(B) The flight activities (afternoon) of dragonfly in terms of the number of species and individual related to time and light intensity at Bo Ma Lake.

The maximum ten and nine species of dragonfly were found at Kan Ma Gyi both in the morning and afternoon. The number slightly decreased compared to the second study site although the species number higher. The flight activities trend was also observed to be similar recorded to be higher after 10:30 h (1.2lux). Most common species was T. aurora. During afternoon, individual number was lower than those observed in the morning. However, the mentioned two species were again recorded to be common and almost throughout the study hours of the day (Figures 5A, 5B).

At Pagoda Lake, eight species were recorded to be with the maximum species number during morning study. The number increased along with time, especially at 10:30 h (1.0lux) and after that period. Two species (Brachythemis contaminata and Trithemis aurora) appeared to be common at this study site. In the afternoon study, high numbers of species were recorded from 14:00 to $15: 20 \mathrm{~h}$ (1.0-1.2lux) and decreased either by species or individual number from 15:30 to $16: 00 \mathrm{~h}$ (1.0lux). Two species (B. contaminata and $T$. aurora) were also found to disperse commonly (Figures 6A, 6B).

The flight activity of the number of species and individuals abundance was distributed at Ye Pan Lake both in the study time. The flight activities trend was also observed to be similar since the number being higher after 10:30 h (1.0-1.4lux). Most common species was B. contaminata, Pantala flavescens and T. aurora. During afternoon, individual number was lower than those observed in the morning. However, high numbers of species were recorded from 14:00 to 15:10h (0.8-1.0lux) and decrease either by species or individual number from 15:20 to 16:00h (0.86-0.99lux) (Figures 7A, 7B).

At Bo Ma Lake, maximum of 13 species were recorded to be the maximum species number during morning hour. The number increased with time, especially at 09:30 h (0.91ux) and after that period. In the afternoon, high numbers of eight species were recorded from 14:00 to 14:50h (0.8-1.0lux) and decrease either by species or individual number from 15:00 to 16:00h (0.6-0.79lux). Two species (Rhyothemis plutonia and R. triangularis) were also found to disperse commonly (Figures 8A, 8B).

At the study site of Ye Pan Lake, the highest of (16) species was observed. Each time, the composition of species was apparently higher than the other three sites. The species T. aurora was the most common at Ye Pan Lake (Figures 7A, 7B). Moreover, T. aurora was also most commonly observed at the remaining four study sites.

\section{Discussion}

During the study period from June 2008 to December 2010, a total of 30 species of 19 genera belonging to three families and three subfamilies was recorded in National Kandawgyi Gardens, Pyin Oo Lwin Township.

Libellulidae was found to be the most dominant family in the present study. In many other studies, this family is also widely represented in surveys elsewhere locally and globally. ${ }^{25-26}$ The relative number of genera (15) and species (27) confined to the respective family Libellulidae and subfamily Libellulinae of the Anisoptera.

Gomphidae is very diverse family with 919 species distributed throughout the world. ${ }^{27}$ However, a single genus and single species (Ictinogomphus decoratus melaenops) was recorded as the representative of family Gomphidae in the present work. Again Subramanian ${ }^{27}$ discussed a total number of dragonfly species to be 34 including the family Gomphidae, Aeshnidae, Cordulegasteridae and Libellulidae in Peninsular India. In the whole, family Gomphidae comprised only $6 \%$. Also in the study, family Gomphidae represented $4 \%$.

Subramanian ${ }^{27}$ stated that Aeshnidae has cosmopolitan distribution and 412 species are known world-wide. He also further recorded that Aeshnidae comprised $15 \%$ of the total collected species in Peninsular 
India. In the present study, only two genera and two species under family Aeshnidae, representing $8 \%$ was recorded. In addition, most of the species under Aeshnidae are diurnal while a few species are crepuscular as stated by Subramanian. ${ }^{27}$ Anax guttaus confined to family Aeshnidae among the present recorded species was collected in the late evening (18:45h) indicating this species to be a nocturnal.

Different species of dragonfly were found at different sites. ${ }^{11}$ Most species of Odonata are restricted to specific habitats both during larval and adult life stages especially the stenotopic species (limited to a single habitat). ${ }^{28,29}$ Certain habitats had a greater amount of certain species than others did. Concerning habitat, it was found under study that flower beds are the highest assemblages of the species number and species individual representing the preferred habitat type of dragonfly species. On the other hand, the orchard farm showed the lowest assemblages of the species number and species individual, indicating the unfavoured habitat of dragonfly species. This might be attributed to the fact that orchard farm is located far distance from the water bodies whereas flower beds are dominant near the water bodies and weedy plants used as perching substrates so that the abundance of dragonflies centered in the area surrounded by water in associated with their life history. Furthermore, the early stages (nymphs) are wholly aquatic, and require waters of sufficient depth, quality and duration in which to grow and transform into winged adults. It was noted in the present study that Brachythemis contaminata, Orthetrum sabina sabina, $O$. pruinosum neglectum, Trithemis aurora and Pantala flavescens which were abundantat flower beds. However, Brachydiplax farinosa, Neurothemis fulvia, Orthetrum luzonicum, Rhyothemis triangularis and R. plutonia were dominant in the swamp forest.

On seasonal concerns, Saunders ${ }^{11}$ stated that the relative representation of the most abundant species lives in specific areas during a specific time period. Present study showed three species to be highly specific to either habitat or period. Polycanthagyna erythromelas was only recorded in March at public area and Diplacodex nebulosa, Urothemis signata in September at flower beds.

The population dynamics of insect adults were carried out in the influence of precipitation, relative humidity and maximum, minimum and average temperatures on its population density being evaluated. ${ }^{29}$ The species variation in line with season was observed also in the present study. Neurothemis fulvia was very abundant in the swamp forest in February and March; however it declined in May during two year study (2009-2010). In contrast, Ryothemis plutonia was very abundant in the swamp forest and public area in May. This species was mostly in flight and air assemblages. Again, Orthetrum luzonicum was very plentiful in the swamp forest during June, July and August. Species of inmature Crocothemis servilia servilia was rich in the Lily Garden in August. This is probably due to the changes of weather (rainfall, temperature, wind force and humidity) in the NKGs.

It would have been able to see a definite decline in certain adult species abundance by early September in the study in Michigan. ${ }^{11}$ In the present work, though species occurrence was highest in September and October, the individual numbers of each species were decline obiviously from early September to February throughout the study period. Except two species (Orthetrum sabina sabina and O.pruinosum neglectum), the individual numbers of the recorded species increased during early September. Moreover, most spcies were not found in January and December. In NKGs, daily temperature and humidity range between $13.7-19.2^{\circ} \mathrm{C}$ and $80.2-92.3 \%$ in January and December. On the other hand, two species (Pantala flavescens and Trithemis aurora) were found nearly throughout the year of study period. This might be attributed to their best adaptation to the climatic variations to which normally they are submitted.

Corbet $^{30}$ classified dragonfly species to be overwintered. Overwintering adults began to fly in early spring on the first sunny days. Copulation and oviposition occurred in May. Adults of this generation were active in flight until summer. Odonata species from this group were characterized by a mass synchronous emergence from the end of April until the beginning of June ("spring species").

In the study area, NKGs involved in three seasons; hot season (March-May), rainy season (June-October) and cold season (November-February). Under present study, the seasonal occurrence of dragonfly species varied in terms of the number of species and individual. In rainy season particularly in October and cold season (November) highest species numbers was observed. However, highest individual number was recorded in the hot season (May), rainy season (June and July). One species, Diplacodes nebulosa was only found in rainy season (September). Likewise, Trithemis festiva was observed only in November. Ten species namely Ictinogomphus decoratus melaenops, Polycanthagyna erythromelas, Brachydiplax farinosa, Hydrobasileus croceus, Rhodothemis rufa, Rhyothemis phyllis, R.variegata variegata, Tetrathemis irregularis, T. platyptera, Zyxomma petiolatum were recorded in hot and rainy seasons. A total of 13 species occurred in all three seasons indicating available throughout the year. These species contained Brachythemis contaminata, Crocothemis servilia servilia, Neurothemis fulvia, Orthetrum glaucum, O. luzonicum, O. pruinosum neglectum, $O$. sabina sabina, $O$. triangulare triangulare, Pantala flavescens, Rhyothemis triangularis, Trithemis aurora and T. pallidinervis.

Odonata are highly sensitive to factors such as the amount of sunlight and water movement. ${ }^{31}$ Their distribution, seasonality and inter-habitat variation are strongly restricted by climatic factors, especially temperature. ${ }^{9}$ In the comparative species number and weather condition during 2008 and 2009 (June, September and December), the differences were found. The rainfall, temperature and humidity were high in December 2008 and September 2009 compared to December, 2009 and September, 2008. However, wind force was higher in 2008 than 2009. On the whole, it seems that the abundance of dragonflies is likely to increase with the temperature and humidity and decrease with wind force. During the study period of three years, December was found to be comprised of the highest species number in 2008 and 2010, but it declined in 2009 due to lower rain fall, temperature, wind force and humidity in 2009.

Lutz and Pittman ${ }^{32}$ documented that some species of dragonfly terminated flight activity when the weather dramatically changed or when cloudiness increased. The present study showed the dragonfly species were more active during the mid-day. Moreover, the number of species and individuals were related to light intensity, time and habitat type. It was recorded that when the light intensity is suddenly high the dragonfly numbers become higher both in terms of species and individuals. Moreover, when the weather abruptly changed (e.g. rainy, windy and cloudy), the number of species and individuals noticeably decreased in the study sites. Throughout the study period, it was also recorded that the flight activities of dragonfly in terms of the number of species and individuals were highest at 09:00-11:00h (0.8-1.4lux). This finding may be associated with fine weather, thermoregulation and high food availability. In the afternoon record from 14:00-16:00h (0.6-1.2lux), the flight activities of dragonfly in terms of the number of species and individuals were lower than in the morning record. In afternoon, sun light was usually reduced which probably retard the activity of the dragonfly.

A suitable habitat is determined by temperature and water 
chemistry which is then influenced by rainfall, watershed and aquatic vegetation. The other important factor influencing habitat selection is predation. ${ }^{11}$ Under the present study, the sampling sites (Pagoda Lake, Kan Ma Gyi, Bo Ma Lake and Ye Pan Lake) showed the differences in the fluctuation of species number and individual. Among four sites, Ye Pan Lake comprised the highest species number and species individual whereas Pagoda Lake possessed the lowest species number and individual. This finding may be related to the water quality. Water turbidity of Ye Pan Lake and Pagoda Lake was 4.47 N.T.U and 14.6 N.T.U respectively. Compared to WHO, standard unit of turbidity was 5 N.T.U. The turbidity of Pagoda Lake was thus apparently higher than the standard quality. Moreover, Ye Pan Lake has the loads of aquatic plants and more favourable predation sites rather than Pagoda Lake.

Based on the present findings, it was disclosed that the nature of the habitat, favourable perching sites and suitable weather condition influence on the abundance, seasonal occurrence and flight activity of dragonfly species. And since the dragonflies were incidence especially during the morning and afternoon when the intensity of sunlight was higher, the nature "lovers of sunshine" is justified.

\section{Acknowledgments}

None.

\section{Conflicts of interest}

The authors declared there is no conflict of interest.

\section{References}

1. Asaithambi M, Manickavasagam S. Odonata of Annamalai University, Annamalainagar, Tamil Nadi, India. Zoos 'Print Journal. 2002;17(2):704706.

2. Calvert PP. Odonata. In: R.H Porter \& Dulau Co, editors. Biologia Centrali Americana: Insecta: Neuroptera, London; 1902.

3. Michiel NK, Dhondt AA. Effect of emergence characteristics on longevity and maturation on the dragonfly Sympetrum danae (Anisoptera: Libellulidae). Hydrobiologia. 1989;174:149-158.

4. McElwey SJ. Territorial behavior of Odonata. 2008.

5. Corbet PS. Dragonflies: Behaviour and ecology of Odonata. Harley books, Colchester; 1999. 829p.

6. Corbet PS. Biology of Odonata. Annual Review of Entomology.1980;25:189-217.

7. Johnson DM. Behavioural ecology of larval dragonflies and damselflies. TREE. 1991;6(1):8-13.

8. Harvey IF, Corbet PS. Territorial behavior of larvae enhances mating success of male dragonflies. Animal Behaviour. 1985;33(2):561-565.

9. May ML. Thermal adaptations of dragonflies. Odonatologica. 1978;7(1):27-47.

10. Dijkstra KDB, Clausniter V. An annotated checklist of the dragonflies (Odonata) of Eastern Africa, with critical lists for Ethiopia, Kenya, Malawi, Tanzania and Uganda, New records and taxonomic notes; 2005.

11. Saunders R. The emergence and flight seasons of different Odonata species in particular habitats. Practicum in Aquatic Biology. 1998.

12. Fraser FC. The fauna of British India, including Ceylon and Burma, Odonata Vol I. London: Taylor and Francis; 1933.
13. Fraser FC. The fauna of British India, including Ceylon and Burma, Odonata Vol II. London: Taylor and Francis; 1934.

14. Fraser FC. The fauna of British India, including Ceylon and Burma, Odonata Vol III. London: Taylor and Francis; 1936.

15. Orr AG. Dragonflies of Peninsular Malaysia and Singapore. Natural History Publications; 2005.

16. Bisht MS, Khkreti M, Shantibhusan. Relative abundance and distribution of bird fauna of Garhwal Himalaya. Eco Env \& Cons. 2004;10(4):451460 .

17. Maung Myaing. Taxonomic descriptions of some Odonata of Burma. M.Sc Thesis. Department of Zoology, Arts and Science, Myanmar, University of Mandalay; 1974.

18. Ohn Mar. Taxonomic study on insects of the Order Odonata in Yangon Division. M.Sc. Thesis. Department of Zoology, Myanmar: University of Yangon; 1997.

19. Thu Zar. Odonate fauna in some townships of Mandalay Division and Shan States with reference to species diversity. PhD Thesis. Zoology Department, Myanmar: University of Mandalay; 2005.

20. Khin Myat Hmwe. Taxonomic study on the Odonates of Patheingyi area. M.Sc, Thesis. Department of Zoology, Myanmar: University of Yangon; 2000 .

21. Group MS. A study on some Odonata in Meiktila University Campus. M.Sc Term Paper. Myanmar: Meiktila University; 2006. 127p.

22. Group I M.S. Taxonomic study on some dragonflies and damselflies of Pakokku and it's environ. M.Sc Term Paper. Myanmar: Pakokku University; 2006. 117p.

23. Lei Lei Thin. Comparative study on wing venation of some odonates in Patheingyi Township. M Res Thesis. Department of Zoology, Myanmar: University of Yadanabon; 2008. 90p.

24. Khin Hnin Soe. Species community, seasonal abundance and distribution of the Odonates in Thanlyin and Kyaktan environs. PhD Thesis. Department of Zoology, Myanmar: University of Yangon; 2011.

25. Norma RYM, Sofian A, Ismail ZM. Diversity and distribution of Odonata (dragonflies and damselflies) in the fresh water swamp lake, Tasek Bera, Malaysia. Hydrobiologia. 2001;459(1-3):135-146.

26. Salmah CMR. Studies of aquatic insects, with emphasis on dragonflies (Insecta: Odonata) as a tool in biomonitoring of freshwater ecosystem. The School of Biological Science, Universiti Sains Malaysia. Bulletin. 2001;1:7-10.

27. Subramanian KA. Dragonflies and damselflies of Peninsular India. Bangalore, India: A field guide; 2005.

28. Orr AG. A guide to the dragonfly of Borneo; their identification \& biology. Malaysia: Natural History Publication; 2003.

29. Watanabe M, Matsuoka H, Taguchi M. Habitat selection and population parameters of Sympertrum infuscatum (Selys) during sexual mature stages in a cool temperate zone of Japan (Anisopetra: Libellulidae). Odonatologica. 2004;33:169-179.

30. Corbet PS. Seasonal regulation in British dragonflies. Nature. 1954; $174: 655$.

31. Wahizatul AA, Julia J, Amirrudin A. Diversity and distribution of dragonflies (Insecta: Odonata) in Sekayu recreational forest, Terengganu. Journal of Sustainability Science and Management. 2006;1(2):97-106.

32. Lutz PE, Pittman AR. Some ecological factors influencing a community of adult Odonata. Ecology. 1969;51(2):279-284. 
Appendix IA Data Analysis of ANOVA for Habitat Disparity of Dragonfly Species

\section{Descriptives}

\begin{tabular}{|c|c|c|c|c|c|c|c|c|}
\hline & \multirow{2}{*}{$\mathbf{N}$} & \multirow{2}{*}{ Mean } & \multirow{2}{*}{ Std. Deviation } & \multirow{2}{*}{ Std. Error } & \multicolumn{2}{|c|}{ 95\% Confidence interval for mean } & \multirow{2}{*}{ Minimum } & \multirow{2}{*}{ Maximum } \\
\hline & & & & & Lower bound & Upper bound & & \\
\hline Public area & 3 & 11.33 & 5.508 & 3.18 & -2.35 & 25.01 & 6 & 17 \\
\hline Bamboo forest & 3 & 4.33 & 1.528 & 0.882 & 0.54 & 8.13 & 3 & 6 \\
\hline Swamp forest & 3 & 17 & 4 & 2.309 & 7.06 & 26.94 & 13 & 21 \\
\hline Orchard & 3 & 1 & 0 & 0 & I & 1 & I & I \\
\hline Adjacent to natural forest & 3 & 4.33 & 1.528 & 0.882 & 0.54 & 8.13 & 3 & 6 \\
\hline Flower beds & 3 & 17.67 & 6.658 & 3.844 & 1.13 & 34.21 & 10 & 22 \\
\hline Ponds & 3 & 4 & 2.646 & 1.528 & -2.57 & 10.57 & 2 & 7 \\
\hline Total & 21 & 8.52 & 7.181 & 1.567 & 5.26 & 11.79 & I & 22 \\
\hline
\end{tabular}

ANOVA

\begin{tabular}{llllll}
\hline & Sum of squares & df & Mean Square & F & Sig. \\
\hline Between Groups & 826.57 & 6 & 137.76 & 9.42 & 0 \\
Within Groups & 204.67 & 14 & 14.62 & & \\
Total & 1031.24 & 20 & & & \\
\hline
\end{tabular}

Appendix I B Data Analysis of ANOVA for Habitat Disparity of Dragonfly Species Individuals Descriptives

\begin{tabular}{|c|c|c|c|c|c|c|c|c|}
\hline & \multirow{2}{*}{$\mathbf{N}$} & \multirow{2}{*}{ Mean } & \multirow{2}{*}{ Std. Deviation } & \multirow{2}{*}{ Std. Error } & \multicolumn{2}{|c|}{ 95\% Confidence interval for mean } & \multirow{2}{*}{ Minimum } & \multirow{2}{*}{ Maximum } \\
\hline & & & & & Lower bound & Upper bound & & \\
\hline Public area & 3 & 963 & 997.64 & 575.99 & -1515.26 & 3441.26 & 110 & 2060 \\
\hline Bamboo forest & 3 & 17.67 & 6.11 & 3.53 & 2.49 & 32.84 & II & 23 \\
\hline Swamp forest & 3 & 748.33 & 466.26 & 269.2 & -409.93 & 1906.6 & 242 & 1160 \\
\hline Orchard & 3 & 17.33 & 11.24 & 6.49 & -10.59 & 45.25 & 5 & 27 \\
\hline Adjacent to natural forest & 3 & 52 & 32.08 & 18.52 & -27.69 & 131.69 & 24 & 87 \\
\hline Flower beds & 3 & 933 & 669.62 & 386.61 & -730.44 & 2596.44 & 163 & 1379 \\
\hline Ponds & 3 & 28.67 & 29.3 & 16.91 & -44.11 & 101.45 & 7 & 62 \\
\hline Total & 21 & 394.29 & 597.81 & 130.45 & 122.17 & 666.41 & 5 & 2060 \\
\hline
\end{tabular}

\section{ANOVA}

\begin{tabular}{llllll}
\hline & Sum of squares & df & Mean Square & F & Sig. \\
\hline Between Groups & 3821311.62 & 6 & 636885.27 & 2.68 & 0.06 \\
Within Groups & 3326252.67 & 14 & 237589.48 & & \\
Total & 7147564.29 & 20 & & & \\
\hline
\end{tabular}

